\title{
PENDAMPINGAN PEMBAYUN SEBAGAI TOKOH ADAT SASAK DI KELAS IBU DALAM PERENCANAAN PERSALINAN KE TENAGA KESEHATAN DI KABUPATEN LOMBOK TIMUR
}

\author{
Fachrudi Hanafi \\ Fakultas Kedokteran Universitas Islam Al-Azhar \\ J1. Unizar No.20 Turida Mataram \\ rudi_pskk@yahoo.co.id
}

\begin{abstract}
ABSTRAK
Latar belakang : Selama ini kegiatan di kelas ibu hamil hanya dihadiri oleh ibu hamil tanpa didampingi oleh keluarga atau pendamping lainnya sehingga saat selesai mengikuti kelas ibu, ibu hamil mengalami kesulitan dalam membuat keputusan untuk perencanaan persalinannya. Dalam penelitian budaya ini peneliti mencoba mengikutsertakan pembayun yang merupakan tokoh adat sasak yang menjadi tokoh sentral dalam suatu upacara perkawinan adat sasak lombok dalam mendampingi ibu hamil di kelas ibu untuk ikut membantu ibu hamil dalam memantabkan perencanaan persalinan ke tenaga kesehatan.

Tujuan: mengetahui pendampingan pembayun dalam kelas ibu dalam perencanaan persalinan ke tenaga kesehatan.

Metode: Rancangan penelitian adalah pre dan post test design with control yang merupakan jenis quasi experiment. Sampel yang diperoleh sebanyak 4 klas ibu yang diambil dari masing-masing wilayah puskesmas. Peserta kelas ibu yang didampingi pembayun terdiri atas 10 ibu hamil dan 3 pembayun, sedangkan peserta kelas ibu yang tidak didampingi pembayun terdiri atas $10 \mathrm{ibu}$ hamil dan 10 keluarga terdekat. Pengumpulan data menggunakan kuesioner untuk mendapatkan pengetahuan peserta dan wawancara mendalam pada ibu hamil untuk mendapatkan komitmen pembayun.

Hasil: Terjadi peningkatan pengetahuan semua peserta kelas ibu sesudah pelaksanaan kelas ibu. Semua ibu peserta melahirkan di tempat pelayanan kesehatan baik di RS, puskesmas dan bidan praktek swasta. Wawancara mendalam diperoleh bahwa sebagian besar ibu yang didampingi pembayun melahirkan ke tenaga kesehatan atas kemauan sendiri berdasarkan dari perencanaan yang telah dibuat bersama pembayun saat mengikuti kelas ibu. Ibu hamil yang didampingi pembayun menyatakan bahwa kemauan untuk melahirkan ke tenaga kesehatan selain karena informasi yang didapatkan saat di kelas ibu juga karena anjuran pembayun saat kunjungan ke rumah yang merupakan bentuk komitmen pembayun. Disamping itu para ibu ini juga menganggap bahwa pembayun merupakan orang yang ditokohkan atau menjadi panutan di masyarakat sehingga apapun yang disampaikan saat kunjungan rumah itu akan selalu diikuti. Kesimpulan: pendampingan pembayun pada semua ibu hamil memberikan pengaruh berupa semua ibu peserta melahirkan ke tenaga kesehatan.
\end{abstract}

Kata Kunci : Pembayun, Kelas Ibu, Perencanaan Persalinan.

\section{LATAR BELAKANG}

Selama ini kelas ibu yang ada di desa dalam pelaksanaannya hanya dihadiri oleh ibu hamil tanpa didampingi oleh keluarga. Akibat yang bisa terjadi bila klas ibu tidak dihadiri oleh keluarga antara lain bila terjadi suatu permasalahan kesehatan yang ada pada ibu hamil tidak diketahui oleh keluarga ibu hamil tersebut sehingga tidak dapat diputuskan segera oleh keluarga. Kadang-kadang persalinan yang sudah direncanakan ke tenaga kesehatan tidak direalisasikan, keputusan yang segera harus diambil bila ibu hamil harus dirujuk sering terlambat karena keputusan masih dimusyawarahkan dengan keluarga terutama keluarga yang sangat berpengaruh. Keputusan yang terlambat ini akan berdampak pada risiko tinggi kematian ibu hamil tersebut. 
Di kehidupan masyarakat sasak ada beberapa tokoh paternalistic yang menjadi panutan atau berpengaruh di masyarakat seperti tuan guru/kyai, kepala desa, tokoh adat dll. Salah satu tokoh adat disini adalah pembayun. Bila pada suatu kelas ibu hamil tokoh adat seperti pembayun diikutsertakan sebagai pendamping ibu hamil dalam perencanaan persalinan maka akan menjadikan semua informasi kesehatan ibu hamil yang disampaikan pada saat kelas ibu akan dapat diketahui pula oleh pendamping ini. Dengan keikutsertaan pembayun sebagai pendamping ini diharapkan keputusan yang diambil oleh ibu hamil dalam perencanaan persalinan menjadi lebih pasti. sehingga pada akhirnya dapat memberikan dampak dalam menurunkan kematian ibu dan bayi baru lahir terutama pada masyarakat suku sasak pulau Lombok.

Tujuan penelitian ini adalah untuk mengetahui peran pembayun di kelas ibu hamil dalam meningkatkan perencanaan persalinan ke tenaga kesehatan.

\section{METODE PENELITIAN}

Rancangan penelitian yang digunakan adalah pre dan post test design with control yang merupakan jenis penelitian quasi experiment. Kelompok intervensi adalah ibu hamil di kelas ibu yang didampingi pembayun, sedangkan kelompok kontrol adalah ibu hamil di kelas ibu yang didampingi suami/keluarga. Sampel yang diperoleh sebanyak 4 klas ibu yang diambil dari masing-masing wilayah puskesmas yang mempunyai cakupan persalinan nakesnya paling rendah di Kabupaten Lombok Timur. Kelas ibu yang diberikan intervensi pesertanya terdiri atas $10 \mathrm{ibu}$ hamil dan 3 pembayun sebagai pendamping, sedangkan kelas ibu yang tidak diberikan intervensi terdiri atas 10 ibu hamil dan 10 keluarga terdekat sebagai pendamping. Variabel penelitian ini meliputi komitmen pembayun, pengetahuan pembayun, suami dan ibu hamil, notifikasi penolong persalinan dan nifas Pengumpulan data menggunakan kuesioner untuk mendapatkan pengetahuan peserta dan wawancara mendalam pada ibu hamil untuk mendapatkan komitmen pembayun. Analisis dilakukan secara deskriptif dan uji t test.

\section{HASIL PENELITIAN}

\section{Pengetahuan Ibu Hamil}

Hasil penelitian terhadap pengetahuan peserta kelas ibu yang terdiri dari 20 orang di masing-masing desa dapat dilihat pada tabel berikut. 
Tabel 1. Distribusi Frekwensi Pengetahuan Ibu Hamil Pre dan Post Test masing-masing Desa di Kabupaten Lombok Timur $(n=20)$.

\begin{tabular}{cccc}
\hline Desa & Kategori & Pre $(\%)$ & Post $(\%)$ \\
\hline \multirow{3}{*}{ Sakra } & Baik & 0 & 5 \\
& Cukup & 0 & 55 \\
\cline { 2 - 4 } & Kurang & 100 & 40 \\
\cline { 2 - 4 } Padamara & Baik & 0 & 5 \\
& Cukup & 0 & 55 \\
\cline { 2 - 4 } & Kurang & 100 & 40 \\
\cline { 2 - 4 } Toya & Baik & 0 & 5 \\
\cline { 2 - 4 } & Cukup & 0 & 55 \\
\cline { 2 - 4 } & Kurang & 100 & 40 \\
\hline \multirow{3}{*}{ Pandan Wangi } & Baik & 0 & 5 \\
& Cukup & 0 & 30 \\
\cline { 2 - 4 } & Kurang & 100 & 5 \\
\cline { 2 - 4 } & & & 0
\end{tabular}

Hasil penelitian menunjukkan dengan uji $\mathrm{t}$ test untuk melihat perubahan bahwa pengetahuan peserta sebelum dan pengetahuan juga menunjukkan hasil sesudah mengikuti pembelajaran di kelas yang signifikan $(\alpha) 0,00$ dengan derajat ibu sesuai hasil pre dan post test kepercayaan $(\mathrm{CI})$ 95\%. Ini berarti telah mengalami peningkatan. Analisis statistik terjadi perubahan pengetahuan.

\section{Persalinan ke Tenaga Kesehatan}

Hasil penelitian didapatkan bahwa berbeda-beda pula. Secara rinci ibu-ibu yang mengikuti kelas ibu saat distribusinya dapat dilihat pada tabel persalinan ditolong oleh tenaga yang berikut.

berbeda-beda dan di tempat yang

Tabel 2. Distribusi Jumlah Responden yang Melahirkan ke Tenaga Kesehatan dan Non Kesehatan dan Tempat Persalinan Masing-Masing Desa

\begin{tabular}{lccccc}
\hline \multirow{2}{*}{ Nama Desa } & \multicolumn{5}{c}{ Tempat Persalinan (\%) } \\
\cline { 2 - 6 } & Polindes & Puskesmas & $\begin{array}{c}\text { Bidan Praktek } \\
\text { Swasta/BPS }\end{array}$ & RS & $\begin{array}{c}\text { Tenaga Non } \\
\text { Kesehatan }\end{array}$ \\
\hline Sakra & 50 & 20 & 30 & & \\
\hline Padamara & 90 & & & 10 & \\
\hline Toya & 60 & 10 & 10 & 20 & \\
\hline Pandan Wangi & 60 & & 30 & 10 & \\
\hline
\end{tabular}

Berdasarkan tabel di atas ke tenaga kesehatan dengan tempat didapatkan bahwa semua ibu hamil yang persalinan yang bervariasi. mengikuti kelas ibu semuanya melahirkan 


\section{Kesepakatan Pembayun}

Kesepakatan pembayun dibuat saat akhir pembelajaran kelas ibu selesai dilaksanakan. Bentuk kesepakatannya berupa surat pernyataan pembayun untuk selalu siap membantu ibu hamil melakukan perencanaan persalinan ke tenaga kesehatan. Semua pembayun yang terlibat semuanya membuat kesepakatan di atas lembar surat pernyataan dengan mengetahui kepala desa.

\section{Wawancara Mendalam Pasca \\ Melahirkan}

Wawancara ini dilakukan di semua desa terpilih dengan cara mengunjungi semua ibu hamil yang pernah mengikuti kelas ibu dan saat ini sudah melahirkan. Wawancara menggunakan bantuan instrumen lembar wawancara mendalam.

Hasil wawancara mendalam yang dilakukan pada semua ibu peserta kelas ibu didapatkan bahwa semua pembayun telah melakukan kunjungan rumah sebelum ibu melahirkan. Saat kunjungan tersebut pembayun menyampaikan dan mengingatkan dengan memberikan pesanpesan untuk selalu memeriksakan dan melahirkan ke tenaga kesehatan. Ibu hamil yang telah dikunjungi oleh pembayun tersebut semuanya melahirkan ke tempat pelayanan kesehatan.

\section{PEMBAHASAN}

Pengetahuan ibu hamil sebelum pelaksanaan kelas ibu (pre test) didapatkan masih relatif rendah yaitu semuanya masuk dalam kategori kurang. Namun setelah mendapatkan pembelajaran di kelas ibu selama 3 hari dan kemudian dilanjutkan dengan post test, didapatkan terjadi peningkatan pengetahuan dimana sebagian besar pengetahuan peserta sudah masuk dalam kategori cukup dan sebagian kecil sudah ada yang masuk dalam kategori baik.

Terjadinya perubahan peningkatan pengetahuan ini akibat beberapa faktor antara lain penjelasan materi yang diberikan sangat jelas apalagi penyampaiannya ditunjang dengan menggunakan bahasa daerah, tidak membosankan, adanya dialok interaktif/diskusi yang dibangun secara baik oleh fasilitator. Disamping itu gambar-gambar yang disajikan sangat jelas, menarik dan mudah diterima. Hal ini juga didukung dari hasil wawancara mendalam yang dilakukan beberapa waktu setelah selesainya pelaksanaan kelas ibu. Namun, disisi lain hasil pengetahuan yang kurang pada semua peserta sebelum kelas ibu dilaksanakan adalah sesuatu yang wajar karena semua peserta masih belum mengetahui seluruh isi dari materi yang akan diajarkan. 
Sebelum pelaksanaan penelitian ini terlebih dahulu dibuat suatu kesepakatan dengan pembayun untuk bersedia terlibat semua kegiatan penelitian. Kesepakatan ini dibuat berdasarkan kesadaran dari pembayun dan tidak ada unsur paksaan. Hasil kesepakatan adalah pembayun harus bisa membuktikan bahwa selalu siap dalam membantu ibu hamil. Kesiapan ini bisa diketahui dari hasil wawancara mendalam yang didapatkan bahwa pembayun telah melakukan kunjungan ke rumah ibu hamil peserta kelas ibu sebelum ibu hamil tersebut melahirkan.

Saat berkunjung tersebut pembayun selalu memberikan pesan-pesan berupa mengingatkan atau menyarankan ibu untuk selalu memeriksakan dan melahirkan ke bidan dan untuk tidak percaya akan mitos, mengingatkan akan tanda bahaya kehamilan dan persalinan serta mengikuti KB setelah melahirkan.

Akan tetapi ada sebagian kecil ibu ada yang tidak pernah dikunjungi pembayun karena mungkin rumah ibu yang jauh dari rumah pembayun dan ada juga ibu yang belum sempat dikunjungi karena ibu hamil tersebut sudah melahirkan terlebih dahulu.

Semua ibu hamil yang mengikuti kelas ibu semuanya melakukan persalinan di tempat pelayanan kesehatan. Akan tetapi ibu hamil ini tempat persalinannya berbeda-beda. Dan hal ini memang tergantung pada keinginan masingmasing ibu hamil ini dan beberapa ibu hamil melahirkan di RS karena rujukan dari polindes/bidan desa. Semua hasil laporan persalinan ini diperoleh dari buku laporan bidan desa.

Melihat hasil ini peneliti menyimpulkan bahwa ibu hamil ini sudah memahami pentingnya melakukan persalinan ke tenaga kesehatan. Pada ibu hamil yang dirujuk ke RS, sebelumnya sudah datang untuk bersalin ke polindes tetapi karena tidak bisa ditolong di polindes maka dirujuk ke RS. Dalam proses merujuk ini tidak ada permasalahan di dalam keluarga ibu hamil karena keluarga ibu hamil sudah memahami pentingnya dilakukan rujukan ini. Disamping itu peran pembayun sangat menentukan saat berkunjung ke rumah ibu hamil sehingga dapat meningkatkan pengaruhnya pada ibu hamil dan juga keluarganya akan pentingnya melahirkan ke tenaga kesehatan.

Pengaruh pembayun ini dikarenakan bahwa pembayun di dalam masyarakat desa di lombok dianggap oleh ibu hamil dan keluarganya sebagai tokoh adat yang disegani tidak hanya pada saat upacara adat perkawinan saja tetapi juga dalam kehidupan keseharian masyarakat desa, sehingga apapun pesan yang 
disampaikan oleh pembayun akan selalu dipatuhi atau diikuti.

Pada desa lain yang pelaksanaan kelas ibunya didampingi oleh keluarga disini semua ibu hamilnya juga melahirkan ke tenaga kesehatan. Hal ini dikarenakan pengaruh keluarganya yang sangat menentukan. Keluarga yang sangat berpengaruh ini bisa memberikan masukan kepada ibu hamil karena sebelumnya sudah dibekali pengetahuan saat mengikuti kelas ibu. Disamping itu keluarga yang diikut sertakan di kelas ibu adalah keluarga yang paling berpengaruh di keluarga ibu tersebut sehingga hal ini yang menyebabkan semua ibu hamil di desa yang menjadi kontrol/pembanding semuanya melahirkan di tenaga kesehatan.

\section{KETERBATASAN PENELITIAN}

Beberapa keterbatasan yang ditemukan pada penelitian ini adalah wawancara yang dilakukan tidak menanyakan lebih dalam kenapa ibu tersebut memilih untuk melahirkan ke tenaga kesehatan apakah karena memang pengaruh ketokohan dari pembayun yang mendasari ibu harus mengikuti semua pesan yang disampaikan atau karena inisiatip dari ibu sendiri setelah mengikuti kelas ibu hamil.

\section{KESIMPULAN}

Berdasarkan hasil penelitian yang didapat maka dapat disimpulkan bahwa ibu hamil sudah memahami pentingnya melakukan persalinan ke tenaga kesehatan. Hal ini dikarenakan peran pembayun di dalam masyarakat desa selain dianggap sebagai tokoh adat yang disegani tidak hanya pada saat upacara adat perkawinan saja tetapi juga dalam kehidupan keseharian masyarakat desa, sehingga apapun pesan yang disampaikan akan selalu dipatuhi/diikuti oleh masyarakat termasuk ibu hamil ini.

\section{SARAN}

Setiap kegiatan kelas ibu yang dilakukan oleh Puskesmas diharapkan agar mengikutsertakan pula pembayun sebagai tokoh adat perkawinan yang disegani oleh masyarakat.

\section{DAFTAR PUSTAKA}

Dinas Kesehatan Propinsi NTB. Profil Kesehatan Propinsi NTB Tahun 2014.

Depkes RI, 2009. Sistem Kesehatan Nasional. Jakarta: Depertemen Kesehatan RI.

Depkes RI, 2008. Laporan Hasil Riset Kesehatan Dasar Tahun 2007, Jakarta

Kemenkes RI, 2009, Buku Paket Pelatihan Kader Kesehatan Dan Tokoh Masyarakat Dalam Pengembangan Desa Siaga, edisi 2009. 
Kemenkes RI, 2009, Pedoman Perencanaan Persalinan dan Pencegahan Komplikasi (P4K).

Kemenkes RI. 2012. Upaya Percepatan Penurunan Angka Kematian Ibu dan Bayi Baru Lahir di Indonesia. Ditulis oleh Direktorat Bina Kesehatan Anak 4 juli 2012.

Kemenkes RI. 2012. Lembar Balik Selamat Datang di Kelas Ibu Hamil. Ditulis oleh Direktorat Bina Kesehatan Ibu

Kemenkes RI. 2013a. Pedoman Umum Manajemen Kelas Ibu.

Kemenkes RI. 2013b. Pelatihan Kelas Ibu, Buku Panduan Peserta

http://www.gizikia.depkes.go.id/artikel/up aya-percepatan-penurunan-angkakematian- ibu-dan-bayi-baru-lahirdi-indonesia

https://pkbmdaruttaklim.wordpress.com/2 013/02/06/upacara-perkawinan/

Ratmaja, L. 2011. Muatan Lokal Budaya Sasak, Gumi Sasak, Mataram.

Kurniati, T.S. Wacana dalam adat perkawinan Sorong Serah Aji Krama di kalangan masyarakat Sasak, Lombok Timur, Nusa Tenggara Barat : Sebuah tinjauan Etnolinguistik, tesis.

Sindonews.com, 26 September 2013. Data SDKI 2012, angka kematian ibu melonjak. http://nasional.sindonews.com/read /2013/09/25/15/787480/data-sdki2012-angkakematian-ibu-melonjak. Diakses 19 Oktober 2013 